\title{
En el bosque
}

\section{Julia Reyes}

En un bosque lejano habitaban distintos animales y una gran variedad de plantas. Era un lugar hermoso para vivir, con un río que pasaba por el bosque y hacía que el hábitat fuera adecuado y saludable para la flora y fauna.

Una hermosa rosa de color rojo vivía cerca del río. Su color y su delicadeza de pétalos cautivaban a todos cuando pasaban. Los animales y plantas la nombraron la reina del bosque.

Sin embargo, en el mismo lugar vivía un sapo. El sapo era el más feo de todo el bosque, porque su piel era áspera de color verde con negro y con un canto horrible.

Cuando el sapo se acercaba a la rosa, ella quería que se fuera y que no estuviera cerca suyo, porque él era feo y ella muy hermosa. Le daba vergüenza que un animal tan feo pudiera estar con ella.

Un día la rosa le dijo al sapo:

- Sapo, no quiero verte cerca de mí y de este río, eres feo y me haces sentir mal con tu fealdad.

Tristemente el sapo se marchó a buscar otro hogar para alejarse de la rosa.

El tiempo pasó y un día cuando el sapo pasó por su antigua vivienda vio a la rosa marchita y muy triste. Toda su hermosura se había desvanecido, sus hojas eran de color café y tostada y sin pétalos rojos.

El sapo le preguntó:

- ¿Rosa, qué te pasó? - La rosa le contestó:

-Desde que te fuiste, los insectos me han comido y cada día muero un poco más. El sapo le contestó

- "Sí, cuando yo vivía aquí me comía todos los insectos".

\section{Moraleja}

"Aprende a querer a las personas que están a tu alrededor, sin importar su apariencia". 